\title{
Alterations in Piglet Small Intestine after Cholesterol Deprivation
}

\author{
J. NEU, W. R. WALKER, E. L. ENGELHARDT, C. Y. WU-WANG, M. B. RAO, M. R. THOMAS, \\ AND P. A. GIMOTTY \\ Department of Pediatrics and Biostatistics [P.A.G.], University of Florida College of Medicine, \\ Gainesville, Florida 32610
}

\begin{abstract}
Mammalian cells require cholesterol for normal cell function. This requirement can be fulfilled by endogenous biosynthesis or by extracellular supplementation. Infants fed with human milk receive greater quantities of cholesterol than those fed commercial formulas. Whether this lack of cholesterol in commercial formulas poses a threat to normal neonatal cell function is not known. We compared small intestinal microvillus membrane fluidity, hydrolase activities, protein concentration, permeability to nonabsorbable markers, and weight gain in neonatal piglets receiving restricted intake of isocaloric formulas containing either normal amounts of cholesterol $(145 \mathrm{mg} / \mathrm{dl})$ or very low levels of cholesterol $(<2 \mathrm{mg} / \mathrm{dl})$. Using the fluorescent probe, diphenylhexatriene, and fluorescence polarization, microvillus membranes from cholesterol deprived piglets demonstrated higher fluidities than did microvillus membranes from animals fed normal concentrations of cholesterol. Cholesterol-deprived animals, even though their caloric intake was similar to cholesterol-fed animals, demonstrated a net weight loss per animal whereas the cholesterol-fed animals demonstrated a weight gain. These results demonstrate that in a pig model on a restricted intake, cholesterol deprivation alters the biophysical properties of the microvillus membrane. (Pediatr Res 22: 330-334, 1987)
\end{abstract}

\section{Abbreviations}

MVM, microvillus membrane

DPH, 1,6-diphenyl-1,3,5-hexatriene

Little is known about the effect of dietary cholesterol on the developing small intestine. Human infants who are breast-fed have a higher cholesterol intake compared to formula-fed infants. Certain other mammalian species have even higher cholesterol concentrations in their milk, prompting inferences that cholesterol may be an important functional component of the diet. Some concepts that may mitigate the possible functional role of cholesterol in milk are: first, the membrane-stabilizing effect of cholesterol is a phenomenon described for many membrane systems ( $1-3)$; however, relationships between dietary concentrations and the development of biophysical properties and function of mammalian small intestinal membrane have not yet been established. Second, alterations in endogenous biosynthesis of cholesterol have been shown to modulate the cholesterol content

Received January 26, 1987; accepted April 15, 1987

Reprint requests and correspondence Josef Neu, M.D., Associate Professor in Pediatrics, Division of Neonatology, University of Florida College of Medicine, Box J-296, JHMHC, Gainesville, FL 32610.

Supported by Mead Johnson Nutritional Group. and motional freedom (fluidity) of lipids in the MVM (4) of the small intestine. The alterations in cholesterol content are associated with changes in the transport properties of glucose and bile acids in the ileum (5). In the rat, as the transport of active bile acids in the ileum develops during maturation, MVM fluidity decreases inversely with the increase in cholesterol-to-phospholipid ratio (5). These factors suggest a relationship between concentration of membrane cholesterol and function. Even though deprivation of dietary cholesterol may elevate endogenous biosynthesis of cholesterol (6), no evidence is available to demonstrate that the neonatal small intestine can adapt to cholesterol deprivation by accelerating cholesterol biosynthesis. Whether dietary cholesterol deprivation produces a threat to normal small intestinal function is unknown. The purpose of this investigation was to determine the effects of cholesterol deprivation on the small intestinal MVM of the neonatal pig on a restricted formula intake.

\section{METHODS}

Animals. Neonatal pigs were farrowed at the University of Florida Swine Center. On day 110 of gestation, sows were moved to a farrowing room environmentally controlled for temperature and light. There, both animals and facilities were scrubbed and disinfected to provide as nearly aseptic conditions as possible. Sows were attended at farrowing to determine time of birth. Individual piglet litters were allowed to suckle from the mother for approximately $24 \mathrm{~h}$. Piglets in each litter were then removed from the sow at the same time and placed in individual cages, which were kept in a temperature-controlled animal laboratory $\left(26-30^{\circ} \mathrm{C}\right)$. Prior to initiation of formula feeding, all animals were given an intramuscular injection of $200 \mathrm{mg}$ of iron (Gleptosil) and $100 \mathrm{mg}$ of tetracycline (Liquamycin) for prophylaxis of iron-deficiency anemia and bacterial infection.

Dietary treatments. All piglets were fed a formula consisting of $6.7 \mathrm{~g}$ fat ( $45 \%$ soy and $55 \%$ coconut oil), $4.5 \mathrm{~g}$ protein, $5.5 \mathrm{~g}$ corn syrup solids, and $100 \mathrm{kcal}$ for every $100 \mathrm{ml}$ formula. Vitamin and mineral composition was as follows: $\mathrm{Ca} 1.81 \mathrm{~g} /$ liter, Cu $2.5 \mathrm{mg} /$ liter, Fe $54 \mathrm{mg} / \mathrm{liter}, \mathrm{Mg} 0.138 \mathrm{mg} /$ liter, Mn 2.0 $\mathrm{mg} /$ liter, P $1.15 \mathrm{~g} /$ liter, K $1.05 \mathrm{~g} /$ liter, Na $0.36 \mathrm{~g} /$ liter, Zn 0.36 $\mathrm{mg} /$ liter, $\mathrm{Cl} 0.65 \mathrm{~g} / \mathrm{liter}, \mathrm{I} 116 \mu \mathrm{g} / \mathrm{liter}, \mathrm{Cu} 0.078 \mathrm{~g} / \mathrm{liter}$, thiamine $1.42 \mathrm{mg} /$ liter, riboflavin $1.47 \mathrm{mg} / \mathrm{liter}$, niacin $16.1 \mathrm{mg} /$ liter, $\mathrm{B}_{6}$ $1.82 \mathrm{mg} /$ liter, pantothenic acid $8.0 \mathrm{mg} /$ liter, $\mathrm{B}_{12} 7.2 \mu \mathrm{g} / \mathrm{liter}$ biotin $0.26 \mathrm{mg} /$ liter, folic acid $0.37 \mathrm{mg} /$ liter, vitamin A 1720 IU/liter, vitamin D 78 IU/liter, vitamin E 35 IU/liter, vitamin $\mathrm{K} 0.52 \mathrm{mg} /$ liter, and methionine $1.21 \mathrm{~g} /$ liter. Piglets were randomly assigned within litter to one of two dietary regimens: one consisted of this low-cholesterol formula and the other formula with cholesterol added (ICN Nutritional Biochemistry, Cleveland, $\mathrm{OH}$ ), approximating cholesterol concentrations found in sow's milk $(145 \mathrm{mg} / \mathrm{dl})$. Lactulose and mannitol were added to both formulas at concentrations of 5.8 and $2.2 \mathrm{mM}$, respectively. 
Since cholesterol is difficult to solubilize in water, it was mixed with the formula overnight in a refrigerated room in closed containers using a magnetic stirrer. To determine whether precipitation of added cholesterol occurred, samples of milk to be given to the cholesterol supplemented animals were analyzed. and $>80 \%$ of the added cholesterol was consistently detectable. thus validating differences in the amount of cholesterol fed to the piglets. Three litters of piglets were fed these formulas for 7 days and then sacrificed. The first two litters were fed by a tubewithin-a-tube method which consisted of placing a $3 .(0-\mathrm{mm}$ internal diameter endotracheal tube into the esophagus and threading a 6-French feeding tube through it and into the stomach. Both tubes were sutured to the side of the animal's snout and were secured further by use of a circumferential ring of tape around the snout and tubes. Piglets in the third litter were fed in individual cages with troughs, and each was given the same volume of formula. Both tube- and trough-fed animals received formula five times a day $(0800,1200), 160(0,2000)$, and 240() $\mathrm{h})$ : unconsumed formula was recorded for trough-fed animals. No differences in quantity of feeding were observed between cholesterol-supplemented and cholesterol-deprived animals in either the tube-fed or trough-fed groups. For both groups, piglet feedings were restricted in comparison to ad libitum feeding.

Sacrifice and sample collection. A baseline blood sample was drawn from the superior vena cava before feeding was initiated: thereafter blood samples were drawn approximately $2 \mathrm{~h}$ after feeding. Samples were analyzed for lactulose. mannitol, and cholesterol. All piglets were sacrificed randomly between 080()$_{-}$ $1200 \mathrm{~h}, 12-18 \mathrm{~h}$ from their last feeding. Before sacrifice, piglets were anesthetized with pentobarbital. 50() $\mathrm{mg} / \mathrm{kg}$. Intestines were removed while the animals were still alive to reduce the cell sloughing and necrosis that occurs at death. After removal of the intestine, another aliquot of blood was removed by cardiac puncture and the animals were killed with a lethal dose of pentobarbital.

MVM preparation and biochemical analyses. Small intestines of piglets were cut into three equal portions representing proximal, middle, and distal segments. Each segment was gently flushed with $0.9 \%$ ice-cold saline. MVMs were isolated by the Malathi modification (7) of the Schmity method (8). A $1 \%$ homogenate was made in $50 \mathrm{mM}$ mannitol-2 $\mathrm{mM}$ Tris solution (pH 7.1).

Purification of MVMs in all samples was validated by increased disaccharidase activity in MVM over that from original homogenate; 10 determine this, specific activity per mg of protein of purified membrane was divided by specific activity of homogenate (purification ratio). The mean purification ratio for maltase was $18 \pm 3$ (mean \pm SE:M: $n=24$ ). There were no significant differences in the purification ratios between cholesterol-fed versus cholesterol-deprived groups. MVM samples were found to show very little NaK-ATPase activity (less than $5 \%$ of total ATPase activity) when analyzed by the method of Garg (' al. (9), thus validating that the preparations had minimal basolateral membrane contamination.

Disaccharidase activities were measured by the method described by Tsuboi 't al. (10) and expressed as $\mu$ mol glucose per min for units of enzyme activity and $\mu \mathrm{mol}$ glucose per min per $\mathrm{mg}$ of protein for specific activity. Protein in the homogenate and brush border membrane fractions was measured by the method of lowry et al. (11).

Membrane fluidity studies were performed using a stock solution of (0.0) $1 \mathrm{M}$ DPP (3) in tetrahydrofuran. On each day of the fluorescence studies, an aliquot of this stock solution was freshly diluted to $10 \mu \mathrm{M}$ using ().()2 $\mathrm{M} \mathrm{Na}_{2} \mathrm{HPO}_{4}$. $\mathrm{pH}$ 7.4. and stirred for $2 \mathrm{~h}$. An aliquot of MVM containing $50 \mu \mathrm{g}$ of protein was diluted to total buffer volume of $2.4 \mathrm{ml}$ and incubated at $37^{\circ} \mathrm{C}$. After $2 \mathrm{~h}$. equilibration of DPH was complete, since the fluorescence intensity increased no further. Fluorescence polarization of these samples was measured with an SI M 4000) spectrofluorometer (SI.M Instruments, Inc.. Urbana. IL.) interfaced with an IBM-PC computer After measurement of the intensities of light that were either vertically (If) or perpendicularly (I.) oriented with respect to the direction of the exciting light $(3,11)$. anisotropy $(r)$ was calculated by the following equation:

$$
r_{s}=\frac{\left(\mathrm{I}-\mathrm{I}_{2}\right)}{\left(\mathrm{I}+2 \mathrm{I}_{1}\right)}
$$

Total fluorescence intensities were monitored to detect changes in fluorescence lifetimes. No differences were observed that could account for the fluorescence anisotropy alterations described below.

Emission intensities for each sample were measured at $4^{\circ}$ ( intervals from 40 to $12^{\circ} \mathrm{C}$ using a water bath. Excitation wavelength was set at $365 \mathrm{~nm}$ and emission wavelength at $410 \mathrm{~nm}$.

Membrane fluidity determinations have been expressed using lipid order parameters (13). Lipid order parameters depend largely on the slow decaying static component of the fluorescence anisotropy, $r$. which can be related to the anisotropy, $r$, by the formula $r=4 / 3 r-0.1$, if $0.13<r<0.28$. Since many of our anisotropy $\left(r_{s}\right)$ values were outside of the range for which this semiempirical relation is used. lipid order parameters were not calculated. With DPH being incompletely isotropic, it is questionable whether microviscosity values can be used (13). For these reasons, anisotropy values are used here, as no assumptions are involved in their calculation.

Plasma lactulose and mannitol concentrations were used as markers to differentiate between intestinal permeability of control vs experimental animals. The method described by laker (14) was modified to measure lactulose and mannitol in plasma: a Hewlett-Packard $5830 \mathrm{~A}$ gas chromatograph interfaced with an $18850 \mathrm{~A}$ integrator was used. Plasma samples $(1 \mathrm{ml})$ were deproteinized using $1.0 \mathrm{ml}$ sulfosalicylic acid $(7 \mathrm{~g} / 10() \mathrm{ml})$. After vortexing for $1 \mathrm{~min}$ and centrifuging at $5000 \mathrm{rpm}\left(4^{\circ}\right.$ () for 5 min the supernatant was mixed with resin (Biorad $\triangle G 5() \mathrm{W}-X 8$ 20()-400 mesh, hydrogen form, and Biorad $A G$, 1-X8 20()-40() mesh, chloride form) to remove interfering cations and anions. Following mixing and centrifugation. the supernatant was collected in Mininert microreaction vials (Supelco) Chromatography Supplies. Bellefonte, PA) and dried under $N_{2}$ at $50^{\circ}$ (. Plasma sugars were derivatized by silylation by adding $(0.100 \mathrm{ml}$ Stox oxime-internal standard reagent (Pierce Chemical Co.. Rockford. II.) to a dried sample in a microreaction vial. The sample was heated for $30 \mathrm{~min}$ at $7\left(0-75^{\circ} \mathrm{C}\right.$ and then cooled io room temperature, after which $0.100 \mathrm{ml}$ of trimethylsilylimidazole (Pierce (hemical $(\mathrm{O})$.) was added to the vial. After vortexing for $1 \mathrm{~min}$. the sample was held at room temperature for $30 \mathrm{~min}$. Aliciuots were analyzed using a 6 -ft coiled glass column, $1 / 4-$ inch ()D and $4 \mathrm{~mm}$ ID and packed with $3 \%$ OV-17 on Chromosorb W(HP) $80 / 100$ mesh (Supelco (hromatography Supplies). The gas (hromatograph. fitted with a low-bleed septum. was programmed to start at $150^{\circ} \mathrm{C}$ with increases $10250^{\circ} \mathrm{C}\left(10^{\circ} \mathrm{C} / \mathrm{min}\right)$ after sample injection. Plasma sample peaks were extrapolated against authentic lactulose and mannitol standards (Sigma Chemical (o.. St. Iouis. MO).

(holesterol and phospholipid phosphorus were assayed using the methods of Allain et al. (15) and Bartlett (16). respectively.

Statistical andlysis. The means of animal weight. small intestine wet weight. protein mass, oligosaccharidase activities, and anisotropies at $36^{\circ} \mathrm{C}$ were compared using an analysis of variance for a randomized block design where treatment was a fixed effect and both litter and treatment $x$ litter interactions were random effects (17). Similarly, slopes and $y$-intercepts from the anisotropy vs. temperature linear regressions for each piglet were compared using the same analysis (18). This design was chosen in order to correct for both interlitter variation and for the fact that there were two different methods used to feed the animals (trough and tubes). Means for plasma lactulose and mannitol concentrations and molar ratios of membrane cholesterol to phospholipid phosphorus were compared independently using a one-tailed / test. 


\section{RESULTS}

Of the 20 piglets in the first two litters fed via a constant indwelling gastric tube 14 survived the entire 7-day period of artificial feeding. The remaining piglets showed no signs of diarrhea or significant illness. In several animals, death was directly due to regurgitation and aspiration of formula around a displaced tube. Because of this, the third litter was fed by the controlled trough-feeding technique described in "Methods." Quantity of formula was limited with feeding, and the amounts of residual left in the trough before the next feeding were recorded meticulously. Piglets from litters 1 and 2 receiving normal or low cholesterol feedings were given $2550 \mathrm{ml}$ of formula per piglet by gavage over 7 days. In the third trough-fed litter of animals, the five piglets on normal cholesterol formula received a mean \pm SEM of $3618 \pm 108 \mathrm{ml}$ and the five animals on low-cholesterol formula received $3618 \pm 16 \mathrm{ml}$. Only one of 11 animals in the trough-fed litter died.

Table 1 shows animals' birth weights, sacrifice weights, and total small intestinal weights. Although the birth weights of animals in the normal and low cholesterol groups were essentially the same, the weights at sacrifice did differ significantly; the cholesterol-supplemented animals weighed more than those on low cholesterol formula $(p=0.029)$. Ten of the 14 animals fed normal amounts of cholesterol gained weight, whereas only four of the 10 animals in the low cholesterol groups gained weight. The mean change in weight in the normal cholesterol group was $+92.4 \mathrm{~g}$ per animal compared with $-18.2 \mathrm{~g}$ in the low cholesterol group. No differences were observed in total small intestinal weight or ratio of small intestinal weight to sacrifice weight or in the two treatment groups.

Table 2 shows the results of biochemical measurements from these animals. The serum cholesterol concentrations in the normal and low cholesterol groups did not differ nor did the total small intestinal protein. Sucrase and maltase activities did not differ significantly in either total enzyme activities, specific activity per mg of protein, or regional distribution (proximal, middle, or distal). Only lactase activity per total small intestine appeared to differ between the two groups, with higher levels of activity suggested in cholesterol-fed animals.

MVM fluidity was determined as anisotropy at temperatures ranging from 12 to $40^{\circ} \mathrm{C}$ at $4^{\circ}$ intervals. From these, least-square lines for anisotropy on temperature for each piglet were computed to summarize the relative responses of MVM in the two groups to changes in temperature with respect to anisotropy. The temperature versus anisotropy curves demonstrated linearity. Comparisons of least-square line slopes and y-intercepts therefore provided a reasonable indicator of differences in MVM anisotropy changes with temperature in control versus experimental animals. Table 3 shows the means of the slopes and $y$-intercepts of anisotropy versus temperature curves of DPH in the MVM from proximal, middle, and distal regions of small intestine for both normal cholesterol and cholesterol-deprived animals. The mean slopes of the cholesterol-deprived animals were significantly steeper in the middle and distal regions of the small intestine, while the MVM from cholesterol-deprived animals tended to have higher $y$-intercepts than that from normal cholesterol-fed animals. When individual temperatures were compared for the normal and low cholesterol groups, the anisotropies at $36^{\circ} \mathrm{C}$ were higher in the middle and distal small intestinal regions in the normal cholesterol group than in the low cholesterol group.

Table 4 shows regional differences in MVM cholesterol to protein, phospholipid phosphorus to protein, and cholesterol to phospholipid phosphorus ratios. These suggest a higher cholesterol to phospholipid molar ratio in the cholesterol-fed group which is due mainly to an increase in MVM cholesterol.

Samples of blood, taken from the tube-fed animals at the time of sacrifice, were analyzed for lactulose and mannitol using gas chromatography. Differences in plasma mannitol were not sig-

Table 1. Comparison of piglet birth wt, sacrifice wt, and intestinal wt to body wt $(\mathrm{g} / \mathrm{g})$ at sacrifice*

\begin{tabular}{|c|c|c|c|c|}
\hline & $n$ & Birth wt (kg) & $\begin{array}{l}\text { Sacrifice wt } \\
(\mathrm{kg})\end{array}$ & $\begin{array}{l}\text { Wt intestine } \div \\
\text { wt piglet }\end{array}$ \\
\hline Normal cholesterol & 14 & $1.306 \pm 0.17$ & $1.399 \pm 0.23$ & $0.0389 \pm 0.0071$ \\
\hline $\begin{array}{l}\text { Low cholesterol } \\
p \text { value: difference of means }\end{array}$ & 10 & $\begin{array}{c}1.279 \pm 0.17 \\
0.306\end{array}$ & $\begin{array}{c}1.261 \pm 0.17 \\
0.029\end{array}$ & $\begin{array}{c}0.0392 \pm 0.0048 \\
0.550\end{array}$ \\
\hline
\end{tabular}

* Numbers represent least square means $\pm \mathrm{SE}$ of the mean.

Table 2. Biochemical measurements*

\begin{tabular}{lccccccccc}
\hline & & $\begin{array}{c}\text { Blood } \\
\text { cholesterol } \\
(\mathrm{mg} / \mathrm{dl})\end{array}$ & $\begin{array}{c}\text { Total small } \\
\text { intestine } \\
\text { protein } \\
(\mathrm{mg})\end{array}$ & $\begin{array}{c}\text { Lactase } \\
\text { units per } \\
\text { total small } \\
\text { intestine }\end{array}$ & $\begin{array}{c}\text { Lactase units } \\
\text { per mg } \\
\text { protein }\end{array}$ & $\begin{array}{c}\text { Sucrase } \\
\text { units per } \\
\text { total small } \\
\text { intestine }\end{array}$ & $\begin{array}{c}\text { Sucrase units } \\
\text { per mg } \\
\text { protein }\end{array}$ & $\begin{array}{c}\text { Maltase } \\
\text { units per } \\
\text { total small } \\
\text { intestine }\end{array}$ & $\begin{array}{c}\text { Maltase units } \\
\text { per mg } \\
\text { protein }\end{array}$ \\
\hline $\begin{array}{l}\text { High cholesterol } \\
\text { Low cholesterol }\end{array}$ & $(14)$ & $111.3 \pm 6.6$ & $4592 \pm 145$ & $233 \pm 22$ & $0.049 \pm 0.005$ & $27.2 \pm 5.6$ & $0.007 \pm 0.001$ & $189 \pm 9$ & $0.041 \pm 0.002$ \\
$p$ value: difference \\
of means
\end{tabular}

* Numbers represent least square means $\pm \mathrm{SE}$ of the mean. Enzyme units are expressed as $\mu \mathrm{mol} / \mathrm{min}$.

Table 3. MVM anisotropy measurements for proximal, middle, and distal small intestine segments*

\begin{tabular}{|c|c|c|c|c|c|c|c|c|c|c|}
\hline & \multirow[b]{2}{*}{$n$} & \multicolumn{3}{|c|}{ Slopes $\left(\times 10^{-5}\right)$} & \multicolumn{3}{|c|}{$y$-intercept $\left(\times 10^{-3}\right)$} & \multicolumn{3}{|c|}{$36^{\circ} \mathrm{C}\left(\times 10^{-3}\right)$} \\
\hline & & Proximal & Middle & Distal & Proximal & Middle & Distal & Proximal & Middle & Distal \\
\hline High cholesterol & 14 & $-193 \pm 20$ & $-195 \pm 2$ & $-190 \pm 9$ & $329 \pm 1$ & $333 \pm 1.7$ & $327 \pm 2$ & $259 \pm 9$ & $260 \pm 5$ & $260 \pm 2$ \\
\hline $\begin{array}{l}\text { Low cholesterol } \\
p \text { value: difference of } \\
\text { means }\end{array}$ & 10 & $\begin{array}{c}-258 \pm 24 \\
0.1773\end{array}$ & $\begin{array}{c}-244 \pm 3 \\
0.0048\end{array}$ & $\begin{array}{c}-255 \pm 10 \\
0.043\end{array}$ & $\begin{array}{c}337 \pm 1 \\
0.056\end{array}$ & $\begin{array}{c}340 \pm 2.0 \\
0.105\end{array}$ & $\begin{array}{c}337 \pm 3 \\
0.106\end{array}$ & $\begin{array}{c}241 \pm 10 \\
0.338\end{array}$ & $\begin{array}{c}240 \pm 6 \\
0.070\end{array}$ & $\begin{array}{c}249 \pm 3 \\
0.099\end{array}$ \\
\hline
\end{tabular}

* Each number represents the mean \pm SEM. 
Table 4. MVM protein, cholesterol, and phospholipid phosphorus ratios /mean $\pm S D(n)$ ]

Proximal

Middle

Distal

Cholesterol/protein $\left(\mathrm{mmol}\right.$ cholesterol/mg protein in BBM $^{*} \times$ $10^{-1}$

$\begin{array}{llll}\text { High } & 5.54 \pm 1.49(3) & 9.47 \pm 2.98(4) \dagger & 12.95 \pm 5.47(4) \ddagger \\ \text { Low } & 5.77 \pm 1.7(5) & 5.76 \pm 0.60(5) & 4.97 \pm 1.61(5)\end{array}$

Phospholipid phosphorus/protein (mmol phosphorus/mg BBM protein) $\times 10^{-1}$

High $\quad 4.60 \pm 1.46(3) \quad 7.17 \pm 1.57(4) \quad 6.12 \pm 1.54(4) \S$

Low $\quad 6.04 \pm 2.57(5) \quad 5.65 \pm 1.37(5) \quad 4.50 \pm 1.20(5)$

Cholesterol/phospholipid molar ratio

High $\quad 1.29 \pm 0.54(3) \quad 1.38 \pm 0.52(4) \quad 1.88 \pm 0.62(4) \S$

Low $\quad 1.14 \pm 0.38(5) \quad 1.05 \pm 0.20(5) \quad 1.18 \pm 0.59$ (5)

* Brush border membrane.

$+p<0.025$.

$\ddagger p<0.01$.

$\S p=0.06$.

nificant: mean $\pm \mathrm{SE}$ was $0.0261 \pm 0.0111 \mathrm{mg} / \mathrm{ml}$ in the normal cholesterol-administered group and $0.0521 \pm 0.0219 \mathrm{mg} / \mathrm{ml}$ in the cholesterol-deprived group. Lactulose concentrations were $0.397 \pm 0.061 \mathrm{mg} / \mathrm{ml}$ in the normal cholesterol group and 0.663 $\pm 0.090 \mathrm{mg} / \mathrm{ml}$ in the cholesterol-deprived group; this difference was significant $(p<0.025)$.

\section{DISCUSSION}

Natural milks from many mammalian species, including human milk, contain substantial concentrations of cholesterol. Mature human milk contains $11 \pm 3.2 \mathrm{mg} / \mathrm{dl}$ cholesterol (19), with concentrations up to $150 \mathrm{mg} / \mathrm{dl}(20,21)$. Human colostrum has even higher cholesterol levels-about $50 \%$ more (22). In contrast, commercial infant formulas usually contain less than 2 $\mathrm{mg} / \mathrm{dl}(23)$. The cholesterol content of the low cholesterol formula used in this study was chosen in order to represent commercial formulas. Other mammalian species that have high cholesterol concentrations in their milk include the pig (approximately $145 \mathrm{mg} / \mathrm{dl}$ ) and the rabbit (approximately $85 \mathrm{mg} / \mathrm{dl}$ ) (24).

Whether high concentrations of cholesterol in mammalian milk play a functional role is unknown. It is well recognized that cholesterol is an important component of cell membranes. The plasma membrane is known to have the highest molar ratio of cholesterol:phospholipid in the cell (25). In artificial lipid monolayers, cholesterol lessens the fluidity of lipid acyl side chains above the solid-liquid phase-transition temperature and increases fluidity below it (26). It has been speculated that such modulation in membrane fluidity may protect the cell membrane against temperature shifts (27). In addition, cholesterol composition affects membrane permeability to small molecules, receptorbinding, and amphipathic membrane-bound enzyme activities (28). Since the intestinal MVM is one of the first cell surfaces to be affected by a deficiency of dietary cholesterol, it could be one of the most severely affected surfaces. Theoretically, such a deficiency could alter MVM biophysical and biochemical properties.

We chose neonatal piglets as the animal model to study the effect of cholesterol deprivation on MVM properties because considerable data are available on porcine MVM. Moreover, other investigations have laid a solid foundation on the intestinal closure process in pigs. This process occurs in two stages: the proximal small intestine macromolecular transport ceases within a few days after birth; then about 3 wk later, the distal small intestine undergoes closure (26). We realize that this might not be the most appropriate model for the human neonate since pig milk contains about 10 times the cholesterol content of human milk; however, data obtained from this model could direct our research effort in the human infant.

The reason for the different weight gain in the two groups is unclear. Except for cholesterol content, the formulas fed to the two groups of animals were identical. It is unlikely that cholesterol contributed enough calories to cause differences in weight gain. The trend toward higher lactase activity in the cholesterol supplemented animals might provide a clue. Even though these piglets were not fed a lactose-containing formula, the administration of cholesterol may have increased the activities of other unmeasured digestive enzymes.

The lower slopes obtained from the linear regression of anisotropy on temperature and the higher anisotropy of MVM from normal cholesterol-fed piglets at $36^{\circ} \mathrm{C}$ are likely due to the higher MVM cholesterol concentration; this is supported by the data on Table 4. It has been shown that ileal cholesterol biosynthesis and MVM cholesterol composition and fluidity can be changed by fasting, biliary ligation, or feeding of sodium taurocholate (4). Similar to our studies on cholesterol deprivation, fasting is associated with a lower cholesterol:phospholipid molar ratio and DPH anisotropy in the MVM (4).

In addition to the differences in anisotropy, higher blood lactulose concentrations were detected in cholesterol-deprived pigs, indicating greater intestinal permeability to the normally nonabsorbable marker lactulose. No differences were detected in mannitol permeability. Beach et al. (29) have shown that human premature infants show a decline in lactulose permeability as they mature. Other studies have shown decreases in MVM fluidity with increasing maturity in rats and rabbits $(5,30,31)$. Whether the increased permeability to lactulose in our cholesterol-deprived piglets was due to higher membrane fluidity is unclear.

In summary, our studies show a relationship between cholesterol deprivation, MVM fluidity, and weight gain in the neonatal piglet. These relationships raise the possibility of a functional role for high concentrations of cholesterol in natural milk of the pig. At this time it would be premature to extrapolate these findings to human infants. The adverse effect of dietary cholesterol on human health is well known. However, data on cholesterol intake in infants and children leading to subsequent coronary artery disease remain sparse (32). From the viewpoint of preventative medicine, we should interpret the results in this study cautiously. Further studies would be required to determine whether promotion of small intestinal development may occur when human infants are fed formulas containing cholesterol.

\section{REFERENCES}

1. Horowitz AF 1972 Nuclear magnetic resonance studies on phospholipids and membranes. In: Fox CF. Keith AD (eds) Membrane Molecular Biology. Sinauer Associates, Stamford. CT, pp 164-191

2. Sabine JR 1977 Cholesterol. Marcel Deker, Inc, New York, pp 5-28

3. Shinitzky M, Inbar M 1974 Difference in microviscosity induced by different cholesterol levels in the surface membrane lipid layer of normal lymphocytes and malignant lymphoma cells. J Mol Biol 85:603-615

4. Brasitus TA. Schachter D 1982 Cholesterol biosynthesis and modulation of membrane cholesterol and lipid dynamics in rat intestinal microvillus membranes. Biochemistry 21:2241-2246

5. Heubi JE. Fellows JL 1985 Postnatal development of intestinal bile salt transport: relationship to membrane physiochemicai changes. J Lipid Res 26:797-805

6. Glueck CJ. Tsang R. Balistreri W. Fallat R 1972 Plasma and dietary cholesterol in infancy: effects of early low or moderate dietary cholesterol intake on subsequent response to increased dietary cholesterol. Metabolism 21:11811192

7. Malathi P. Preiser H, Fairclough P 1979 A rapid method for the isolation of kidney brush border membranes. Biochim Biophys Acta 554:259-263

8. Schmitz J, Preiser H, Maestracci D 1973 Purification of the human intestinal brush border membrane. Biochim Biophys Acta 323:98-112

9. Garg LC, Knepper MA, Burg MB 1981 Mineralocorticoid effects on Na-KATPase in individual nephron segments. Am J Physiol 240(Renal Fluid Electrolyte Physiol 9):F536-F544

10. Tsuboi KK. Schwartz SM, Burill PH, Kwong LK. Sunshine P 1979 Sugar hydrolases of the infant rat intestine and their arrangement on the brush border membrane. Biochim Biophys Acta 554:234-248

11. Lowry OH, Rosebrough NJ, Farr AL, Randall RJ 1951 Protein measurements 
with folin phenol reagent. J Biol Chem 193:265-275

12. Shinitzky M, Inbar M 1976 Microviscosity parameters and protein mobility in biological membranes. Biochim Biophys Acta 433:133-149

13. Van Blitterwijk WJ, Van Hoeven RP, Van Der Neer BW 1981 Lipid structural order parameters (reciprocal of fluidity) in biomembranes derived from steady-state fluorescence polarization measurements. Biochim Biophys Acta 644:323-332

14. Laker MF 1979 Estimation of disaccharide in plasma and urine by gas-liquid chromatography. J Chromatogr 163:9-18

15. Allain CA, Poon LS, Chen CSG, Richmond W, Fu PC 1974 Enzymatic determination of total serum cholesterol. Clin Chem 20:470

16. Bartlett GR 1959 Phosphorus assay in column chromatography. J Biol Chem 234:466-471

17. Mendenhall W 1968 Introduction to Linear Models and the Design and Analysis of Experiments. Wadsworth Publishing Company, Belmont, CA

18. Rao CL 1965 The theory of least squares when the parameters are stochastic and its application to the analysis of growth curve. Biometrika 52:447-458

19. Picciano MF, Guthrie HA, Sheehe BS 1978 The cholesterol content of human milk. Clin Pediatr 17:359-362

20. Potter JM, Nestel PJ 1976 The effects of dietary fatty acid and cholesterol on the milk lipids of lactating women and the plasma cholesterol of breast-fed infants. Am J Clin Nutr 29:54-60

21. Mellies MJ, Ishikawa TT, Gartside P, Burton K, MacGee J, Allen K, Steiner PM, Brady D, Glueck CJ 1978 Effects of varying maternal dietary cholesterol and phytosterol in lactating women and their infants. Am J Clin Nutr 31:1347-1354

22. May IG, Kelly HJ 1961 Human milk and cow's milk in infant nutrition. In:
Koen SK, Couries AT (eds) Milk: The Mammary Gland and Its Secretions, Vol 2. Academic Press, New York, pp 265-304

23. Benson J 1981 Fats of human milk and infant formula. In: Lebenthal E (ed) Textbook of Gastroenterology and Nutrition in infancy, Vol 1. Raven Press, New York, pp 553-560

24. Sabine JR 1977 Cholesterol. Marcel Dekker, Inc, New York, pp 188-189

25. Yeagle PL 1985 Cholesterol and the cell membrane. Biochim Biophys Acta $822: 267-287$

26. Quinn AJ, Chapman D 1980 The dynamics of membrane structure. CRC, Crit Rev Biochem 8:1-113

27. Kimelberg HK 1977 The influence of membrane fluidity on the activity of membrane bound enzyme. In: Poste G, Nicholson GL (eds) Dynamic Aspects of Cell Surface Organization: Cell Surface Reviews, Vol. 3. Elsevier Press, Amsterdam, pp 205-293

28. Clarke RM, Hardy RN 1971 Histological changes in the small intestine of the young pig and their relation to micromolecular uptake. J Anat 108:63-77

29. Beach RC, Menzies IS, Clayden GS, Scopes JW 1982 Gastrointestinal permeability changes in the preterm neonate. Arch Dis Child 57:141-145

30. Neu J, Ozaki CK, Angilides KJ 1986 Glucocorticoid-mediated alteration of brush border fluidity in rat small intestine. Pediatr Res 20:79-82

31. Schwartz SM, Hosteter B, Ling S, Mone M, Watkin JB 1985 Intestinal lipid composition and fluidity during development in the rat. Am J Physiol 248:G200-G207

32. Kwiterovich PO 1986 Biochemical, clinical, epidemiologic, genetic, and pathologic data in the pediatric age group relevant to the cholesterol hypothesis. Pediatrics 78:349-362 